\title{
PERUBAHAN ASAM AMINO SURIMI IKAN LELE DENGAN FREKUENSI PENCUCIAN YANG BERBEDA
}

\section{Changes in Amino Acid of Catfish Surimi with Different Washing Frequency}

\author{
Ima Wijayanti*, Titi Surti, Tri Winarni Agustini, Yudhomenggolo Sastro Darmanto \\ Departemen Program Studi Teknologi Hasil Perikanan, Fakultas Perikanan dan Ilmu Kelautan, \\ Universitas Diponegoro Jalan Prof. Soedharto, SH, Kode pos 50275 \\ *Korespondensi: imasetianto@gmail.com \\ Diterima 25 Februari 2014/Disetujui 01 April 2014
}

\begin{abstract}
Abstrak
Pencucian (leaching) merupakan faktor penting dalam proses pembuatan surimi. Penelitian ini bertujuan untuk melihat pengaruh frekuensi pencucian terhadap kandungan asam amino, komposisi proksimat dan karakteristik gel surimi lele (Clarias sp.). Metode yang digunakan adalah eksperimen di laboratorium dengan satu faktor, yaitu perlakuan pencucian dengan 4 taraf berbeda yaitu 1, 2, 3 dan 4 kali dengan menggunakan Rancangan Acak Lengkap (RAL). . Jenis uji yang digunakan adalah Kruskall wallis (non parametrik) dan dilanjutkan dengan uji Dun's Multiple Comparison jika perlakuan berpengaruh nyata. Frekuensi pencucian berpengaruh nyata terhadap komposisi proksimat surimi lele $(\mathrm{p}<0,05)$, yaitu menurunkan kandungan protein, lemak dan meningkatkan kadar air, namun tidak nyata terhadap kandungan mineral. Bertambahnya frekuensi pencucian tidak berpengaruh nyata pada kadar asam amino esensial maupun non esensial kecuali pada asam glutamat. Frekuensi pencucian berpengaruh nyata pada gel surimi lele $(\mathrm{p}<0,05)$. Pada pencucian 3 dan 4 kali kali meningkatkan nilai hardness, deformasi, uji lipat dan uji gigit. Nilai EMC menurun seiring dengan bertambahnya frekuensi pencucian yang menunjukkan kemampuan menahan air pada gel meningkat. Pencucian 3 kali dianggap sudah cukup baik untuk membuat surimi lele karena mampu mempertahankan asam amino surimi lele dan meningkatkan kekuatan gelnya.
\end{abstract}

Kata kunci: asam amino, frekuensi pencucian, surimi lele

\begin{abstract}
Abstrak
Leaching is an important factor in the surimi production process. This study aimed to examine the effect of washing frequency on the amino acid profile, proximate and characteristics of surimi gel catfish (Clarias sp.). The method used was experimental laboratories with different washing treatments ie 1, 2, 3 and 4 times. Experimental design used a completely randomized design (CRD). Data were analyzed Kruskal-Wallis non-parametric method, followed by Dunn's multiple comparison test. Frequency of washing significantly affect the chemical composition of catfish surimi $(p<0.05)$ : lower protein content, fat and water content increase, but no significant effect on the mineral content. Increased frequency had no significant effect on essential and non-essential amino acids except glutamic acid. The frequency of washing gave significant effect on the catfish surimi gel $(\mathrm{p}<0.05)$. Leaching 3 and 4 times increased hardness value, deformation, folding and cutting test. EMC values decreased with increasing frequency of washing demonstrating the ability to hold water in the gel increased. Washing 3 times considered good enough to produce catfish surimi because it was able to to maintain amino acids and increase the gel strength of catfish surimi.
\end{abstract}

Keywords: amino acids, frequency of leaching, surimi catfish

\section{PENDAHULUAN}

Pemerintah melalui Kementerian Kelautan dan Perikanan telah mencanangkan pada tahun 2014 Indonesia menjadi produsen ikan budidaya terbesar di dunia. Potensi sumberdaya lahan yang tersedia, Provinsi Jawa Tengah memiliki potensi lahan budidaya secara keseluruhan mencapai luas 562,247 ha, dengan garis pantai yang mencapai $828,8 \mathrm{~km}$ dan ditunjang dengan kondisi iklim tropisnya 
sangat memungkinan untuk pelaksanaan aktivitas usaha pembudidayaan ikan sepanjang tahun (Diskanlut Jateng, 2013).

Lele merupakan salah satu dari 9 komoditas budidaya yang diunggulkan di Jawa Tengah. Produksi lele Jawa tengah mencapai 62.580 ton pada tahun 2012 (Diskanlut Jateng, 2013). Jawa Tengah termasuk 7 Provinsi penghasil ikan lele di Indonesia dan terbesar kedua setelah Jawa Barat (Dirjen Perikanan Budidaya, 2011). Produksi lele yang cukup besar berpotensi untuk diolah menjadi produk bernilai tambah salah satunya adalah surimi.

Surimi adalah daging ikan yang dihilangkan kulit, tulang dan isi perut secara mekanis yang dicuci dengan air atau larutan garam pada suhu $5-10^{\circ} \mathrm{C}$ dan dengan penambahan cryoprotectan (Shahidi dan Botta 1994). Surimi dapat diproduksi dari ikan air laut maupun ikan air tawar, termasuk daging putih maupun daging merah misalnya alaska pollock, blue whiting, croaker, beloso, sardin, lele dan mata besar. Biasanya spesies tertentu yang digunakan karena alasan mudah penangkapannya dan murah harganya.

Pencucian dalam proses pembuatan surimi bertujuan untuk menghilangkan protein sarkoplasma, darah, lemak dan komponen nitrogen lain dari daging lumat ikan. Asam amino yang merupakan penyusun protein dapat mengalami penurunan selama proses pencucian. Frekuensi pencucian yang berbeda $(1 \mathrm{x}, 2 \mathrm{x}, 3 \mathrm{x}$ dan $4 \mathrm{x})$ pada pembuatan surimi diduga berpengaruh terhadap perubahan kandungan asam amino surimi. Tujuan umum penelitian ini adalah untuk memperoleh teknologi pembuatan surimi dari ikan lele dengan memperhatikan nutrisinya. Tujuan khusus penelitian ini adalah menentukan frekuensi pencucian terbaik dalam pembuatan surimi ikan lele sehubungan dengan kandungan asam amino dan proksimat. Manfaat penelitian ini adalah dapat mengoptimalkan pemanfaatan ikan lele menjadi produk bernilai tambah melalui teknologi pembuatan surimi dengan tetap memperhatikan nilai gizi.

\section{BAHAN DAN METODE \\ Waktu dan Lokasi Penelitian}

Penelitian ini dilakukan pada bulan Juli 2013 sampai dengan bulan November 2013. Penelitian dilakukan di Laboratorium Teknologi Hasil Perikanan Universitas Diponegoro Semarang untuk kegiatan preparasi bahan baku, pembuatan surimi, analisis tekstur, expressible moisture content, $\mathrm{pH}$, uji lipat, uji gigit, uji kesukaan; dan Laboratorium Saraswanti Bogor untuk analisais asam amino.

\section{Bahan dan Alat}

Bahan baku yang digunakan adalah ikanBahan yang digunakan dalam penelitian ini adalah bahan baku, bahan tambahan, bahan pembantu dan bahan kimia untuk analisis. Bahan baku yang digunakan adalah ikan lele yang diperoleh dari petani budidaya ikan lele Boyolali. Lele yang digunakan mempunyai berat rata-rata $200 \pm 50 \mathrm{~g}$. Bahan baku dibeli dalam kondisi segar dan langsung dibuat surimi pada hari itu juga. Bahan tambahan yang digunakan adalah garam untuk pembuatan surimi, bahan pembantu yang digunakan berupa es dan akuades untuk proses pencucian. Bahan kimia yang digunakan antara lain untuk analisis proksimat dan asam amino.

Alat-alat yang digunakan dalam penelitian ini antara lain alat untuk pembuatan surimi dan alat untuk analisis karakteristik fungsional dan mikrostruktur surimi. Peralatan yang digunakan untuk pembuatan surimi antara lain: cool box, wadah air bersih (baskom), pisau filet, talenan, pelumat daging (grinder) elektrik, alat pengepres hidrolik, food processor, waterbath, dan refrigerator. Peralatan yang digunakan untuk analisis karakteristik surimi antara lain: oven, kjeltec system, tanur, sokhlet apparatus, desikator, kertas saring, tabung reaksi, $\mathrm{pH}$ meter digital (Hanna Instrumen Amerika), texture analyzer (TAXT Plus LLOYD Instrument, Inggris), HPLC (Shimadzu, Jepang). 


\section{Metode Penelitian}

\section{Pembuatan Surimi}

Pembuatan surimi dilakukan berdasarkan metode Suzuki (1981) dengan sedikit modifikasi. Kulit, tulang, dan isi perut ikan lele dibuang, selanjutnya daging dihaluskan dengan menggunakan grinder. Daging lumat dicuci dengan air dingin (suhu $\pm 5^{\circ} \mathrm{C}$ ) dengan penambahan garam pada akhir pencucian sebesar $0,1 \%$.

Frekuensi pencucian yang dicobakan adalah $1 \mathrm{x}, 2 \mathrm{x}, 3 \mathrm{x}$ dan $4 \mathrm{x}$ dengan perbandingan ikan dan air 1:4. Daging lumat yang telah dicuci selanjutnya dibuang airnya dengan cara dipres dengan menggunakan alat press hidrolik. Surimi dari masing-masing perlakuan selanjutnya dikemas di dalam plastik polietilen dan disimpan pada refrigerator dengan suhu $4^{\circ} \mathrm{C}$ untuk dianalisis karakteristik fisik, kimia dan sensorik pada hari berikutnya.

\section{Persiapan Pembuatan Gel Surimi (Kamaboko)}

Analisis karakteristik gel surimi dilakukan dengan membuat surimi menjadi bentuk kamaboko. Pembuatan kamaboko dilakukan berdasar metode Balange dan Benjakul (2009). Surimi ditambah dengan garam 3\% (berat/berat) dan dicampur selama 4 menit dengan menggunakan food processor. Sol tersebut kemudian diisikan ke dalam pipa silinder dari stainless steel dengan diameter $2,5 \mathrm{~cm}$ dan kedua sisi atas dan bawah ditutup dengan rapat. Sol tersebut diinkubasi pada suhu $40{ }^{\circ} \mathrm{C}$ selama 30 menit kemudian diikuti dengan pemanasan pada suhu $90^{\circ} \mathrm{C}$ selama 20 menit. Semua gel yang terbentuk didinginkan di dalam air es serta disimpan semalam pada suhu $4^{\circ} \mathrm{C}$ selanjutnya siap untuk dianalisis.

\section{Analisis Proksimat}

Analisis proksimat dilakukan pada surimi dan kamaboko ikan lele. Analisis proksimat terdiri kadar air, protein, lemak, dan abu. Metode yang digunakan dalam analisis proksimat adalah AOAC (2005).

\section{Analisis Asam Amino}

Analisis asam amino dilakukan pada surimi Metode yang digunakan dalam analisis asam amino adalah AOAC (2005) dengan menggunakan HPLC.

\section{Analisis Expressible Moisture Content (EMC)}

Penentuan Expressible Moisture Content dilakukan berdasarkan metode Benjakul et al. (2001) dalam Balange (2009) dengan sedikit modifikasi. Sampel-sampel gel dipotong dengan ketebalan $5 \mathrm{~mm}$ diukur beratnya (X) dan diletakkan diantara 3 lapis kertas Whatman no 4, di bagian dasar 1 lapis dan bagian atas 2 lapis. Beban dengan berat standar $5 \mathrm{~kg}$ diletakkan di atas sampel dan didiamkan selama 2 menit. Sampel diambil dari kertas whatman dan diukur beratnya (Y). Kandungan air yang dapat dinyatakan (Expressible moisture content/EMC) dihitung dengan persamaan berikut:

$$
\operatorname{EMC}(\%)=100[(\mathrm{X}-\mathrm{Y}) / \mathrm{X}]
$$

\section{Analisis pH (Suzuki 1981) \\ Alat $\mathrm{pH}$ meter sebelumnya dikalibrasi terlebih dahulu dengan cara mencelupkan batang probe pada buffer $\mathrm{pH} 4$ kemudian dicelupkan kembali pada buffer $\mathrm{pH} 7$. Sampel yang digunakan sebanyak $5 \mathrm{~g}$ dan ditambah akuades sebanyak $45 \mathrm{~mL}$ kemudian dihomogenkan dengan homogenizer dengan kecepatan $80 \mathrm{rpm}$ selama 2-3 menit, selanjutnya sampel diukur pHnya dengan menggunakan $\mathrm{pH}$ meter yang telah dikalibrasi. \\ Analisis Tekstur (Balange dan Benjakul 2009)}

Analisis tekstur gel surimi berupa deformasi dan kekuatan gel diukur dengan menggunakan sebuah Texture Analyzer model TATX plus (LLOID, Inggris). Gel diequilibrasi dan diuji pada temperatur ruang. Tiga sampel berbentuk silinder dengan panjang $2,5 \mathrm{~cm}$ disiapkan. Deformasi (elastisitas/ deformabilitas) dan hardness diukur dengan menggunakan shperical plunger (diameter 5 $\mathrm{mm}, 60 \mathrm{~mm} /$ menit kecepatan deformasi).

\section{Analisis Sensori}

Analisis sensori dilakukan pada kamaboko lele dengan uji lipat dan uji gigit 
berdasarkan Suzuki (1981). Uji lipat (folding test) merupakan salah satu pengujian mutu gel ikan yang dilakukan dengan cara memotong sampel dengan ketebalan $3 \mathrm{~mm}$. Potongan sampel tersebut diletakkan diantara ibu jari dan telunjuk, kemudian dilipat untuk diamati ada tidaknya retakan pada gel ikan. Skor maksimal pada uji lipat adalah 5 . Uji gigit dilakukan dengan cara menggigit sampel gel surimi antara gigi seri atas dan bawah. Sampel yang diuji mempunyai ketebalan $5 \mathrm{~mm}$ dan berdiameter $\pm 20 \mathrm{~mm}$. Nilai tertinggi pada uji gigit adalah 10 .

\section{Analisis Data}

Rancangan percobaan pada penelitian adalah RAL untuk mengetahui pengaruh perlakuan frekuensi pencucian. Uji lanjut Beda Nyata Jujur (BNJ) dilakukan apabila ANOVA pada perlakuan berpengaruh nyata. Data uji sensorik (organoleptik, uji kesukaan, uji gigit dan uji lipat) dianalisis dengan uji statistika non parametrik Kruskal Wallis (Steel dan Torrie 1993). Uji lanjut perbandingan berganda (Multiple Comparison) dilakukan untuk hasil analisis yang menunjukkan pengaruh yang berbeda nyata.

\section{HASIL DAN PEMBAHASAN}

\section{Perubahan Komposi Proksimat Surimi Lele Akibat Proses Pencucian}

Frekuensi Pencucian berpengaruh nyata pada kadar protein, air dan lemak $(\mathrm{p}<0,05)$, namun tidak berpengaruh nyata pada kadar abu ( $p>0,05)$. Proses pencucian (leaching) dalam pembuatan surimi menurunkan kandungan protein larut air (sarkoplasma) yang selanjutnya meningkatkan konsentrat protein miofibril, kadar lemak juga menurun namun kadar air meningkat. Kadar protein, lemak,air dan abu surimi lele dengan perlakuan pencucian berbeda disajikan pada Tabel 1.

Frekuensi pencucian berpengaruh nyata terhadap kadar protein surimi lele $(\mathrm{p}<0,05)$. Kadar protein surimi menurun $18-25 \%$ dari berbagai frekuensi pencucian yang berbeda. Kadar protein tidak berbeda nyata dengan daging lumat pada pencucian 1 kali. Perbedaan nyata kandungan protein terlihat pada daging lumat dan surimi dengan pencucian 2 kali, 3 kali maupun 4 kali. Penurunan kadar protein diduga karena hilangnya protein sarkoplasma selama proses pencucian. Protein sarkoplasma di dalam daging ikan, terutama albumin menyusun kira-kira 30\% dari total protein otot (Shahidi dan Botta 1994).

Kadar protein surimi dengan pencucian 2 kali, 3 kali maupun 4 kali menunjukkan tidak berbeda nyata, hal tersebut dimungkinkan bahwa pencucian dengan air dingin $(5 \pm 2)^{\circ} \mathrm{C}$ mampu mempertahankan keberadaan protein miofibril. Kadar protein pada pencucian 3 kali menunjukkan penurunan yang terendah yaitu $18 \%$ (dari 13,68\% menjadi 11,17\%). Hasil penelitian ini tidak jauh berbeda dengan penelitian Hoke et al. (2000) yang menunjukkan bahwa kadar protein daging lumat channel catfish yang tidak dicuci mempunyai kadar protein $14,20 \%$ dan menurun menjadi $11,22 \%$ (penurunan kirakira 20\%) setelah pencucian 3 kali dengan suhu $(5 \pm 1)^{\circ} \mathrm{C}$. Hasil penelitian Asgharzadeh et al. (2010) menunjukkan bahwa kadar protein surimi silver carp ( $H$. molitrix) juga mengalami penurunan setelah dicuci 2 kali dari 16,5\% menjadi 14,6\% menurun kira-kira $11,5 \%$. Wijayanti et al. (2012) melaporkan daging lumat ikan lele dengan ukuran $500 \mathrm{~g}$ mempunyai kadar protein yang lebih tinggi yaitu $16,14 \%$, namun demikian setelah pencucian 3 kali kadar protein relatif hampir sama yaitu $11,99 \%$.

Proses pencucian pada pembuatan surimi menggunakan air dengan perbandingan ikan: air $4: 1$. Perbandingan air yang cukup besar tentu akan berpengaruh terhadap kadar air produk meskipun setelah proses pencucian dilakukan proses dewatering (pengepresan) untuk menghilangkan sebagian besar air. Frekuensi pencucian berpengaruh nyata terhadap kadar air surimi $(\mathrm{p}<0,05)$. Frekuensi pencucian relatif meningkatkan kadar air $1-4 \%$. Perbedaan nyata terdapat pada kadar air surimi lele sebelum dicuci dengan surimi yang dicuci 4 kali (meningkat $4 \%$ ). 
Tabel 1 Kadar protein, lemak, air dan abu surimi lele dengan frekuensi pencucian berbeda

\begin{tabular}{ccccc}
\hline \multicolumn{1}{c}{ Perlakuan } & Kadar air (\%) & Kadar protein (\%) & Kadar lemak (\%) & Kadar abu (\%) \\
\hline Pencucian 0 & $74,22 \pm 0,08^{\mathrm{a}}$ & $13,68 \pm 0,38^{\mathrm{b}}$ & $4,77 \pm 0,08^{\mathrm{b}}$ & $3,19 \pm 0,10^{\mathrm{a}}$ \\
Pencucian 1 kali & $76,57 \pm 1,05^{\mathrm{b}}$ & $11,91 \pm 0,03^{\mathrm{ab}}$ & $5,04 \pm 0,25^{\mathrm{b}}$ & $2,39 \pm 0,13^{\mathrm{a}}$ \\
Pencucian 2 kali & $75,08 \pm 0,52^{\mathrm{ab}}$ & $10,74 \pm 0,64^{\mathrm{a}}$ & $4,15 \pm 0,11^{\mathrm{ab}}$ & $3,73 \pm 1,38^{\mathrm{a}}$ \\
Pencucian 3 kali & $75,48 \pm 0,48^{\mathrm{ab}}$ & $11,17 \pm 0,34^{\mathrm{a}}$ & $3,62 \pm 0,15^{\mathrm{a}}$ & $2,66 \pm 0,09^{\mathrm{a}}$ \\
Pencucian 4 kali & $77,32 \pm 0,28^{\mathrm{b}}$ & $10,27 \pm 0,74^{\mathrm{a}}$ & $3,76 \pm 0,13^{\mathrm{ab}}$ & $3,57 \pm 0,25^{\mathrm{a}}$ \\
\hline
\end{tabular}

Superskrip berbeda menunjukkan berbeda nyata $(\mathrm{p}<0,05)$

Suvanich et al. (2000) melaporkan bahwa kadar air pada daging lumat channel catfish (Ictalurus punctatus) sebelum dicuci 70,3\% meningkat menjadi $85,13 \%$ setelah dicuci 2 kali. Asgharzadeh et al. (2010) menambahkan bahwa kadar air surimi ikan silver carp (H. molitrix) juga mengalami peningkatan setelah dicuci 2 kali dari $78,2 \%$ menjadi $82,4 \%$ meningkat kira-kira 5\%. Peningkatan kadar air pada surimi ini disebabkan oleh pencucian karena pembuangan komponen larut air seperti darah, pigmen, protein dan garam-garam mineral dapat menyebabkan kenaikan kemampuan hidrasi daging lumat (Lin and Park 1997).

Lemak merupakan salah satu komponen dalam surimi yang sebaiknya dihilangkan karena dapat mengurangi kualitas gel surimi. Kadar lemak daging lumat ikan lele pada penelitian ini lebih rendah dibandingkan daging lumat lele hasil penelitian Wijayanti et al. (2012) yang mencapai 7,19\%, hal tersebut dimungkinkan karena ukuran berat lele yang digunakan untuk pembuatan surimi berbeda yaitu 500 g per ekor (Wijayanti et al. 2012), sedangkan penelitian ini 200 g per ekor. Komposisi kimia ikan selain dipengaruhi jenis juga dipengaruhi oleh ukuran/umur ikan (Hadiwiyoto 1993).

Frekuensi pencucian pada surimi berpengaruh nyata terhadap kandungan lemak $(\mathrm{p}<0,05)$. Penurunan kadar lemak mencapai $24,1 \%$ dari $4,77 \%$ menjadi $3,63 \%$ pada pencucian 3 kali. Hossain et al. (2004) menyatakan bahwa pencucian berpengaruh terhadap menurunnya kadar lemak daging lumat ikan mas dari 3,1\% menjadi 0,63\%. Asgharzadeh et al. (2010) menyatakan bahwa kadar lemak surimi silver carp ( $H$. molitrix) juga mengalami penurunan dari 2,27\% menjadi $0,74 \%$. Wijayanti et al. (2012) menambahkan bahwa frekuensi pencucian menurunkan lemak surimi ikan lele dari $7,19 \%$ menjadi $4,42 \%$. Penurunan kadar lemak disebabkan selama proses pencucian sebagian besar lemak mengapung di atas permukaan air pencucian dan hilang bersama proses pembuangan air (dewatering) (Suvanich et al. 2000).

Proses pencucian daging lumat kemungkinan menyebabkan mineral larut air dapat terbuang bersama-sama air pencucian. Frekuensi pencucian tidak berpengaruh nyata terhadap kadar abu surimi dengan frekuensi pencucian berbeda ( $p>0,05)$. Pencucian 3 kali menunjukkan penurunan kadar abu terendah yaitu dari 3,19\% menjadi 2,66\%. Kadar abu pada surimi lele ini cenderung lebih tinggi dibanding kadar abu surimi hasil penelitian sebelumnya 1,09\% (Wijayanti et al. 2012). Hoke et al. (2000) menyatakan bahwa kadar abu daging lumat yang belum dicuci $0,66 \%$ turun menjadi $0,51 \%$ setelah dicuci 1 kali. Wijayanti et al. (2012) menambahkan bahwa kadar abu daging lumat lele menurun dari 1,09\% menjadi 0,14 setelah dicuci 3 kali.

Frekuensi pencucian pada proses pembuatan surimi secara umum berpengaruh nyata terhadap komposisi kimia surimi lele. Frekuensi pencucian menurunkan kadar 
protein, lemak, tetapi meningkatkan kadar air.

Komposisi Asam Amino Surimi Lele dengan Frekuensi Pencucian Berbeda

Surimi merupakan intermediete product yang akan diolah menjadi berbagai produk berbasis gel. Produk-produk dengan bahan dasar surimi biasanya disukai oleh semua kalangan masyarakat, oleh sebab itu surimi diharapkan dapat memberi alternatif asupan protein yang berkualitas bagi masyarakat. Surimi tidak hanya dilihat dari sifat fungsionalnya saja namun dilihat pula nilai nutrisinya melalui kualitas protein. Kualitas protein dapat dilihat dari kandungan asam aminonya. Kandungan asam amino daging lumat lele disajikan pada Tabel 2 dan 3.

Hasil analisis asam amino pada daging lumat lele menunjukkan bahwa dari 17 standar asam amino yang ada, terdeteksi 16 asam amino yang terdiri dari 9 asam amino esensial dan 7 asam amino non esensial. Asam amino yang tidak terdeteksi adalah asam amino L-sisteina. Kandungan asam amino daging lumat lele tertinggi adalah asam glutamat dan terendah adalah histidina. Kandungan asam amino esensial pada daging lumat lele cukup lengkap, semua jenis asam amino esensial terdapat di dalamnya yaitu lisina, leusina, isoleusina, treonina, valina, fenilalanina, metionina, histidina dan arginina kecuali triptopan. Hasil penelitian ini sama dengan penelitian sebelumnya oleh Osibona et al. (2009) yang menyatakan bahwa daging lele
C. gariepinus mengandung asam amino esensial yang lengkap kecuali triptophan.

Kandungan asam amino esensial tertinggi pada daging lumat lele adalah lisina. Kandungan asam amino lisina mencapai $11,5 \%$ dari total protein, hasil ini juga ditunjukkan oleh Osibona et al. (2009) yang melaporkan bahwa kandungan asam amino lisina C. gariepinus mencapai 10,64\% dari total protein dan merupakan tertinggi diantara asam amino esensial lainnya. Hass (2014) menyatakan bahwa kandungan lisina sangat tinggi pada ikan, daging, dan produk susu dan lebih tinggi daripada kebanyakan asam amino lainnya dalam biji gandum, kacang-kacangan, dan buah-buahan dan sayuran. Lisina terkonsentrasi di jaringan otot dan memiliki banyak fungsi antara lain membantu dalam penyerapan kalsium dari saluran usus, membantu pertumbuhan tulang, dan pembentukan kolagen.

Kandungan asam glutamat daging lumat lele penelitian ini sekitar $12 \%$ dari total protein. Hasil ini juga tidak jauh berbeda dengan penelitian Osibona et al. (2009) yang melaporkan bahwa daging lele mempunyai kandungan asam glutamat mencapai 17,8\% dari total protein. Mallick (2007) menyatakan bahwa asam glutamat adalah salah satu asam amino yang paling banyak di alam, asam glutamat bebas berada di organ dan jaringan serta ditemukan secara alami dalam hampir semua makanan contohnya susu,

Tabel 2 Kandungan asam amino esensial daging lumat lele

\begin{tabular}{|c|c|}
\hline Jenis Asam amino & Kadar Asam Amino (g/100 g) \\
\hline L-Lisina $\mathrm{HCl}$ & $2,660 \pm 0,008$ \\
\hline L-Leusina & $1,893 \pm 0,071$ \\
\hline L-agrinina & $1,515 \pm 0,018$ \\
\hline L-Valina & $1,290 \pm 0,018$ \\
\hline L-Threonina & $1,290 \pm 0,018$ \\
\hline L-Isoleusina & $1,193 \pm 0,001$ \\
\hline L-Fenilalanina & $1,032 \pm 0,008$ \\
\hline L-Metionina & $0,806 \pm 0,020$ \\
\hline L-Histidina* ${ }^{*}$ & $0,533 \pm 0,004$ \\
\hline
\end{tabular}


Tabel 3 Kandungan asam amino non esensial daging lumat lele

\begin{tabular}{lc}
\hline \multicolumn{1}{c}{ Jenis Asam amino } & Kadar Asam Amino $(\mathrm{g} / 100 \mathrm{~g})$ \\
\hline L-Asam glutamat & $2,826 \pm 0,044$ \\
L-Asam aspartat & $2,610 \pm 0,091$ \\
L-Alanina & $1,401 \pm 0,022$ \\
L-Prolina & $1,230 \pm 0,194$ \\
Glisina & $1,193 \pm 0,081$ \\
L-Serina & $0,988 \pm 0,010$ \\
L-Tirosina & $0,862 \pm 0,013$ \\
\hline
\end{tabular}

Keterangan: $\mathrm{n}=2$

sayuran, makanan laut, unggas, daging, bumbu tradisional kecap ikan, kecap kedelai, dan makanan lainnya. Asam glutamat memberikan rasa "umami" atau gurih pada makanan, oleh sebab itu lele mempunyai rasa yang gurih karena kandungan asam glutamat yang cukup tinggi.

Proses pencucian dalam pembuatan surimi lele secara statistika tidak berbeda nyata terhadap kandungan asam amino esensial pada surimi lele ( $p>0,05)$, namun demikian semakin bertambahnya frekuensi pencucian menunjukkan terjadi penurunan kandungan asam amino esensial. Penurunan yang tidak nyata kemungkinan disebabkan pencucian menggunakan air dingin $(5 \pm 2)^{\circ} \mathrm{C}$ sehingga asam amino pada surimi lele masih bisa dipertahankan. Kandungan asam amino esensial dan non esensial surimi lele dengan frekuensi pencucian berbeda disajikan pada Tabel 4.

Seluruh asam amino esensial pada surimi lele menunjukkan penurunan asam amino tertinggi pada asam amino Lisina yaitu pada pencucian 4 kali yang menunjukkan penurunan mencapai $40 \%$ dari pencucian 1 kali sedangkan yang lain rata-rata penurunan $20 \%$, hal tersebut menunjukkan bahwa asam amino lisina mudah larut di dalam air. Zhao et al. (2009) melaporkan bahwa kelarutan asama amino L-lisina HCL tertinggi pada air dibandingkan dimethyl sulfoxida, glycol, methanol dan ethanol. Synowiecki et al. (1992) menyatakan bahwa pencucian menurunkan komposisi asam amino pada daging terutama histidina, leusina, lisina, fenilalanina, taurina dan valina. Rasekh et al. (1980) melaporkan bahwa asam amino daging lumat yang dicuci mengalami penurunan tertinggi pada asam amino valina mencapai $24 \%$. Adu et al. (1983) menyatakan bahwa pada daging fillet rockfish yang dicuci menunjukkan asam amino histidina mengalami penurunan tertinggi.

Menurut WHO (2007), surimi lele dengan pencucian 3 kali masih dapat memenuhi kebutuhan asam amino lisina yang disarankan yaitu $30 \mathrm{mg}$ per hari per $\mathrm{kg}$ berat badan. Berdasarkan rekomendasi WHO tersebut bahwa surimi ikan lele dengan pencucian 3 kali dengan kadar 2,147\% telah dapat memenuhi kebutuhan asam amino lisina bagi orang dewasa apabila dikonsumsi minimum $100 \mathrm{~g}$.

Asam amino esensial terendah yang terkandung dalam surimi lele dengan pencucian 1-4 kali adalah histidina. Asam amino histidina merupakan asam amino esensial bagi bayi dan anak-anak namun tidak esensial bagi orang dewasa. Kebutuhan asam amino histidina rata-rata adalah 10 $\mathrm{mg} / \mathrm{kg}$ berat badan per hari (WHO 2007). Kandungan histidina surimi lele 0,703 g/100 $\mathrm{g}$ atau $703 \mathrm{mg} / 100 \mathrm{~g}$ pada pencucian $3 \mathrm{kali}$ menunjukkan sudah cukup memenuhi kebutuhan sebagaimana direkomendasikan oleh WHO apabila dikonsumsi sebanyak 100 g per hari.

Frekuensi pencucian juga menunjukkan 
Tabel 4 Kandungan asam amino esensial surimi lele dengan frekuensi pencucian berbeda

\begin{tabular}{lcccc}
\hline \multirow{2}{*}{ Jenis Asam amino } & \multicolumn{4}{c}{ Perlakuan } \\
\cline { 2 - 5 } & Pencucian ke-1 & Pencucian ke-2 & Pencucian ke-3 & Pencucian ke-4 \\
\hline L-Lisina HCl & $3,002 \pm 0,021$ & $2,057 \pm 0,016$ & $2,147 \pm 0,198$ & $1,707 \pm 0,641$ \\
L-Leusina & $1,919 \pm 0,043$ & $1,657 \pm 0,254$ & $1,543 \pm 0,122$ & $1,463 \pm 0,680$ \\
L-Agrinina & $1,688 \pm 0,091$ & $1,604 \pm 0,470$ & $1,415 \pm 0,132$ & $1,311 \pm 0,544$ \\
L-Threonina & $1,300 \pm 0,030$ & $1,223 \pm 0,349$ & $1,141 \pm 0,066$ & $0,987 \pm 0,264$ \\
L-Valina & $1,124 \pm 0,133$ & $0,980 \pm 0,295$ & $0,918 \pm 0,250$ & $0,868 \pm 0,373$ \\
L-Isoleusina & $1,021 \pm 0,121$ & $0,880 \pm 0,249$ & $1,051 \pm 0,194$ & $0,822 \pm 0,120$ \\
L-Fenilalanina & $0,956 \pm 0,021$ & $0,933 \pm 0,305$ & $0,715 \pm 0,049$ & $0,737 \pm 0,525$ \\
L-Metionina & $0,845 \pm 0,038$ & $0,787 \pm 0,187$ & $1,078 \pm 0,078$ & $0,656 \pm 0,223$ \\
L-Histidina & $0,598 \pm 0,028$ & $0,594 \pm 0,216$ & $0,703 \pm 0,046$ & $0,445 \pm 0,113$ \\
L-Asam glutamat & $4,231 \pm 0,238$ & $3,388 \pm 0,239$ & $3,341 \pm 0,224$ & $2,631 \pm 0,944$ \\
L-Asam aspartad & $2,612 \pm 0,118$ & $1,977 \pm 0,028$ & $2,012 \pm 0,086$ & $1,568 \pm 0,471$ \\
L-Treonina & $1,300 \pm 0,030$ & $1,223 \pm 0,349$ & $0,987 \pm 0,066$ & $1,141 \pm 0,264$ \\
Glisina & $1,144 \pm 0,146$ & $0,997 \pm 0,287$ & $0,860 \pm 0,042$ & $0,924 \pm 0,402$ \\
L-Serina & $1,137 \pm 0,013$ & $1,053 \pm 0,233$ & $0,846 \pm 0,000$ & $1,475 \pm 0,627$ \\
L-Prolina & $0,912 \pm 0,026$ & $0,736 \pm 0,138$ & $0,703 \pm 0,074$ & $0,623 \pm 0,400$ \\
L-Tirosina & $0,846 \pm 0,086$ & $0,856 \pm 0,344$ & $0,624 \pm 0,144$ & $0,799 \pm 0,238$ \\
\hline Keterngan: $=2$ & & & &
\end{tabular}

Keterangan: $n=2$

tidak berpengaruh nyata terhadap asam amino non esensial $(\mathrm{p}>0,05)$ kecuali terhadap kandungan asam glutamat $(\mathrm{p}<0,05)$. Kandungan asam glutamat surimi tidak berbeda hingga pencucian 3 kali, namun setelah pencucian 4 kali terdapat perbedaan nyata terhadap kandungan glutamat surimi. Kandungan asam amino non esensial surimi dengan pencucian 1-4 kali cenderung mengalami penurunan. Asam glutamat mengalami penurunan terendah pada pencucian 3 kali dibandingkan asam amino non esensial lainnya.

\section{Nilai pH Surimi Lele dengan Frekuensi Pencucian Berbeda}

Derajat keasaman suatu produk diindikasikan melalui nilai $\mathrm{pH}$. Nilai $\mathrm{pH}$ ikan dan daging biasanya mendekati netral (7) (Berkel et al. 2004). Proses pencucian melarutkan sebagian asam-asam amino dan zat lain yang bersifat asam, hal tersebut tentu akan berpengaruh terhadap derajat keasaman surimi. Nilai pH surimi lele dengan frekuensi pencucian berbeda disajikan pada Gambar 1.

Frekuensi pencucian berpengaruh nyata terhadap nilai $\mathrm{pH}$ surimilele $(\mathrm{p}<0,05)$. Nilai $\mathrm{pH}$ surimi cenderung meningkat seiring dengan penambahan frekuensi pencucian. Daging lumat lele mempunyai $\mathrm{pH}$ yang mendekati netral $(6,87)$ dan meningkat setelah mengalami pencucian. Hasil penelitian ini sejalan dengan penelitian Karthikeyan et al. (2006) yang melaporkan bahwa $\mathrm{pH}$ surimi ikan Threadfin bream sebelum dicuci 7 meningkat menjadi 7,10 setelah dicuci 1 kali dan menjadi 7,15 setelah dicuci 3 kali. Asgharzadeh et al. (2010) menyatakan bahwa nilai $\mathrm{pH}$ surimi silver carp (H. molitrix) juga mengalami peningkatan dari 7 sebelum dicuci menjadi 7,8 setelah dicuci. Wijayanti et al. (2012) menambahkan bahwa nilai $\mathrm{pH}$ surimi lele meningkat dari 6,69 sebelum dicuci menjadi 7,05 setelah dicuci 3 kali. Peningkatan $\mathrm{pH}$ pada surimi seiring dengan penambahan frekuensi pencucian kemungkinan disebabkan oleh terbuangnya 


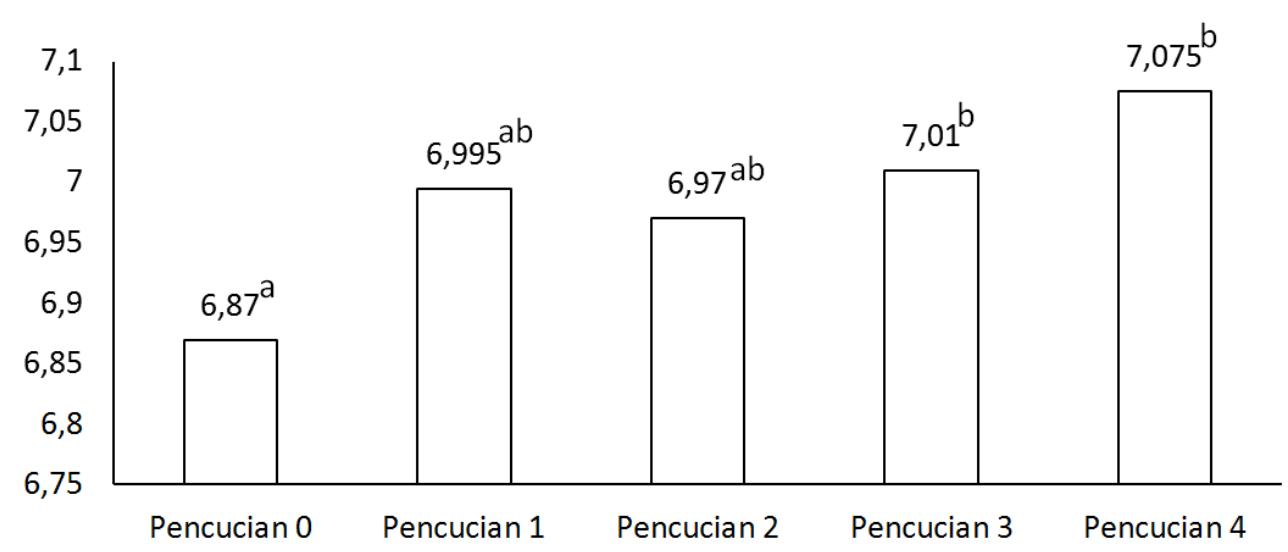

Gambar 1 Nilai pH surimi lele dengan frekuensi pencucian berbeda. Superskrip berbeda menunjukkan berbeda nyata $(\mathrm{p}<0,05)$.

asam amino bebas yang bersifat asam dan zat asam yang larut air lainnya (Suvanich dan Marshal 1998).

Kemampuan dewatering surimi sangat dipengaruhi oleh $\mathrm{pH}$. Nilai WHC terendah terjadi pada titik isoelektrik protein miofibril yaitu pada $\mathrm{pH} 5,3$. Muatan protein menjadi 0 pada titik isoelektrik dan terdapat sejumlah besar ikatan ionik interprotein yang dapat menyebabkan matriks protein berkerut sehingga WHC minimal, oleh sebab itu tidak disarankan melakukan pengepresan (dewatering) pada titik isoelektrik karena kemampuan pembentukan gel akan turun drastis di bawah pH 6 (Richardson 1999).

\section{Tingkat kekerasan dan Deformasi Gel Surimi Lele dengan Pencucian Berbeda}

Pencucian berpengaruh nyata pada peningkatan kualitas tekstur, warna dan bau pada produk akhir apabila komponenkomponen pengganggu dapat dihilangkan selama tahap ini (Park dan Lin 2005). Kualitas tekstur gel surimi dapat dilihat dari nilai hardness maupun nilai deformasi. Nilai hardness gel surimi lele dengan frekuensi pencucian berbeda disajikan pada Gambar 2 . Frekuensi pencucian berpengaruh nyata pada nilai hardness gel surimi $(\mathrm{p}<0,05)$. Gel surimi dengan frekuensi pencucian 1 kali menunjukkan nilai hardness terendah dibanding frekuensi pencucian 2, 3 maupun 4 kali. Penambahan frekuensi pencucian dari
1 kali menjadi 3 kali meningkatkan hardness hingga $34 \%$.

Hasil penelitian lain menunjukkan bahwa surimi Threadfin bream meningkat kekuatan gelnya sekitar $18 \%$ setelah pencucian ditambah menjadi 3 kali (Karthikeyan et al. 2006). Wijayanti et al. (2012) menambahkan bahwa kekuatan gel surimi lele meningkat 10\% setelah dicuci 3 kali. Amiza dan Ain (2012) juga melaporkan bahwa breaking force gel surimi patin pada umumnya meningkat seiring dengan frekuensi pencucian sampai pada pencucian 3 kali dan menurun setelah pencucian 4 kali, hal tersebut kemungkinan disebabkan frekuensi pencucian akan meningkatkan konsentrasi protein miofibril yang berperan didalam peningkatan hardness, breaking strength maupun kekuatan gel yang disebabkan oleh ikatan protein yang lebih kuat.

Deformasi adalah pemanjangan penuh atau kontraksi dari suatu bahan yang terkena gaya secara langsung dengan satuan $\mathrm{cm}$ atau $\mathrm{mm}$ (Kim dan Park 2000). Deformasi gel surimi lele dengan frekuensi pencucian berbeda disajikan pada Gambar 3. Hasil penelitian ini menunjukkan dengan bertambahnya frekuensi pencucian, deformasi meningkat $(p<0,05)$. Deformasi gel surmi tertinggi pada pencucian 3 kali. Deformasi meningkat $20 \%$ setelah pencucian 3 kali dibandingkan dengan pencucian 1 kali. Hasil ini sejalan dengan penelitian 


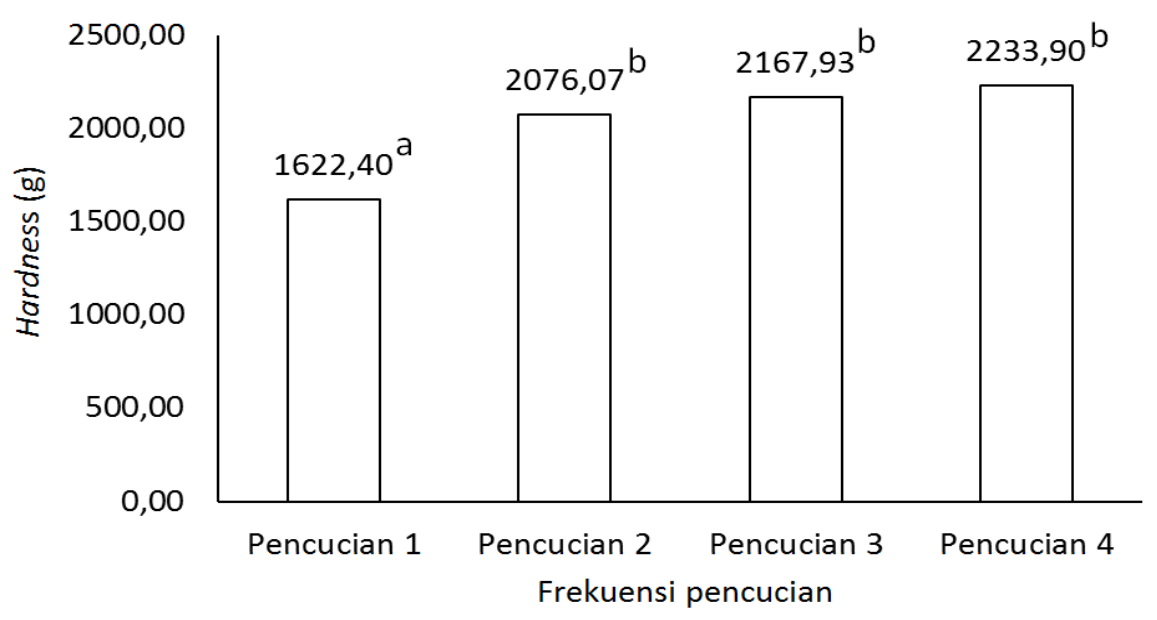

Gambar 2 Nilai hardness (g) gel surimi lele dengan frekuensi pencucian berbeda. Superskrip berbeda menunjukkan berbeda nyata $(\mathrm{p}<0,05)$.

Wijayanti et al. (2012) yang menunjukkan terjadi peningkatan deformasi sekitar 30\% setelah dicuci 3 kali dibandingkan dicuci 1 kali. Peningkatan deformasi menunjukkan peningkatan elastisitas gel surimi. Deformasi juga dipengaruhi oleh konsentrasi protein dan temperatur pemanasan (Luo et al. 2010).

\section{Expressible Moisture Content (EMC) Gel Surimi Lele dengan Pencucian Berbeda}

Expressible moisture content merupakan salah satu metode cepat untuk melihat kandungan air yang keluar pada bahan setelah diberi beban $5 \mathrm{~kg}$. Semakin kecil nilai EMC semakin besar kemampuan menahan air. Chaijan et al. (2010) menyatakan bahwa nilai expressible moisture content terendah pada ikan kembung short bady mackerel mengindikasikan nilai WHC yang tinggi. Nilai EMC gel surimi dengan frekuensi pencucian berbeda disajikan pada Gambar 4.

Frekuensi pencucian berpengaruh nyata terhadap nilai EMC gel surimi lele $(p<0,05)$. Nilai EMC terendah pada pencucian 3 kali. Nilai EMC ini berbanding terbalik dengan hardness dan deformasi. Semakin rendah nilai EMC nilai breakforce dan deformasi semakin tinggi. Nilai EMC yang rendah menunjukkan kemampuan gel surimi menahan air dengan baik sehing berakibat pada peningkatan hardness dan deformasinya. Hasil penelitian ini mirip dengan penelitian Karthikeyan

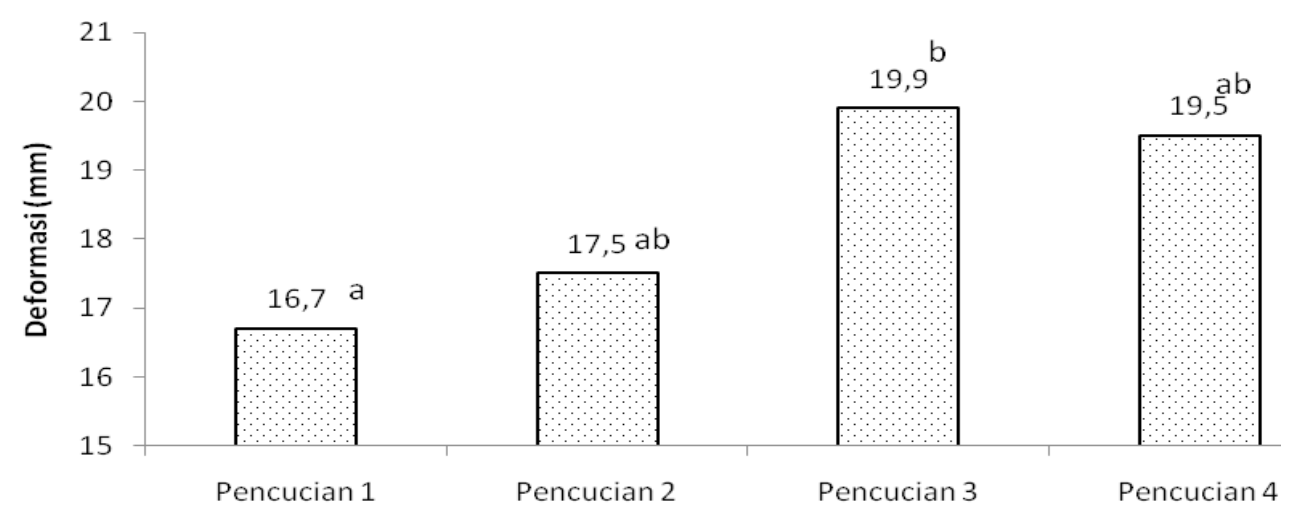

Frekuensi Pencucian

Gambar 3 Deformasi $(\mathrm{mm})$ gel surimi lele dengan frekuensi pencucian berbeda. Superskrip berbeda menunjukkan berbeda nyata $(\mathrm{p}<0,05)$. 


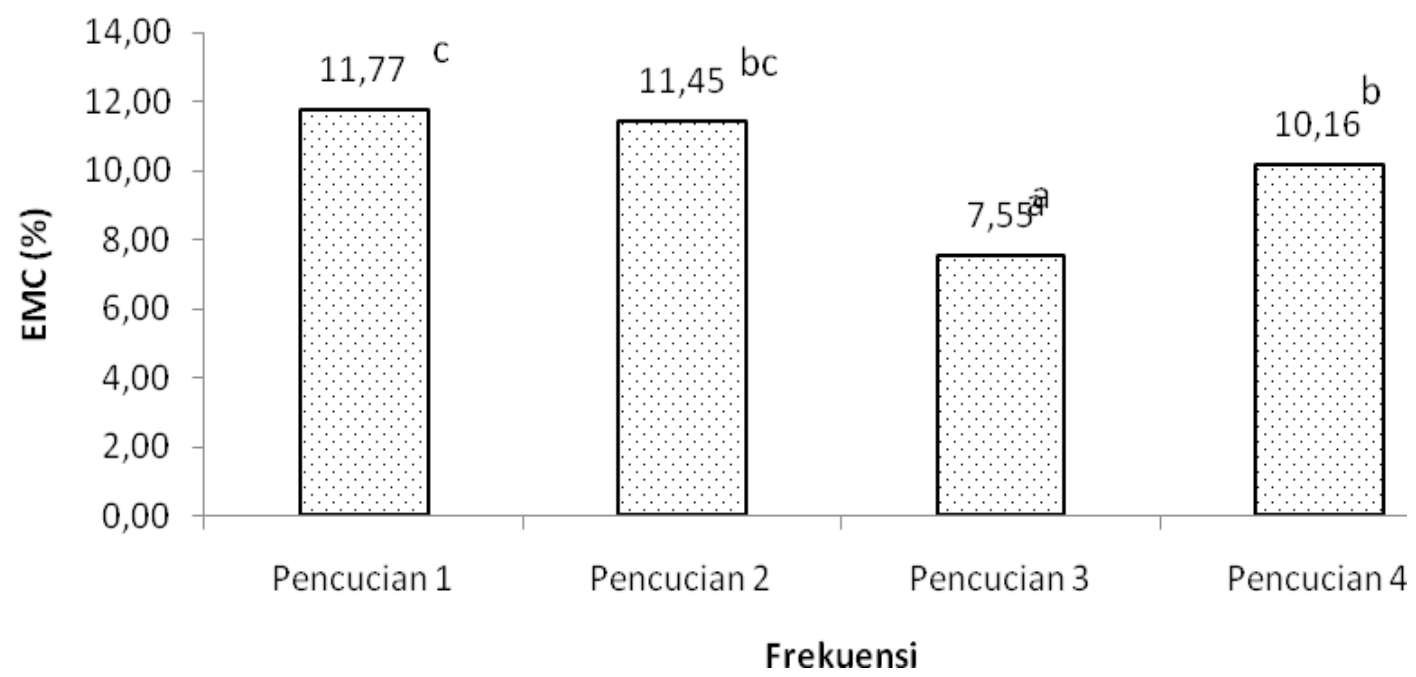

Gambar 4 Nilai expressible moisture content (EMC) dengan frekuensi pencucian berbeda. Superskrip berbeda menunjukkan berbeda nyata $(\mathrm{p}<0,05)$.

et al. (2006) yang menunjukkan nilai expressible water (\%) ikan N. japonicus menurun dari $21,12 \%$ dengan pencucian 1 kali menjadi 19,73\% setelah dicuci 3 kali. Asgharzadeh et al. (2010) melaporkan bahwa nilai expressible moisture ikan silver carp menurun dari 20,8\% sebelum dicuci menjadi $15,2 \%$ setelah dicuci 2 kali. Amiza dan Ain (2012) juga melaporkan bahwa expressible moisture surimi patin menurun seiring dengan meningkatnya frekuensi pencucian sampai pada pencucian 3 kali.

\section{Nilai Uji Lipat dan Uji Gigit Gel Surimi Lele dengan Pencucian Berbeda}

Uji sensorik yang dilakukan meliputi uji lipat dan uji gigit pada kamaboko dari surimi lele dengan frekuensi pencucian yang berbeda. Tabel 5 menjelaskan nilai uji lipat dan uji gigit kamaboko dari surimi ikan lele dengan frekuensi pencucian berbeda.
Frekuensi pencucian berpengaruh nyata pada nilai uji lipat dan uji gigit gel surimi lele dengan frekuensi pencucian berbeda $(\mathrm{p}<0,05)$. Hasil penelitian menunjukkan frekuensi pencucian bertambah maka nilai uji lipat meningkat secara nyata. Pencucian 1 dan 2 kali menunjukkan gel surimi lele retak berangsurangsur setelah dilipat menjadi setengah lingkaran, sedangkan pada pencucian 3 dan 4 kali tidak retak setelah dilipat menjadi setengah lingkaran. Penambahan frekuensi pencucian hingga 3 kali meningkatkan grade gel surimi dari B menjadi A. Hasil penelitian ini sejalan dengan penelitian Wijayanti et al. (2012) yang menunjukkan nilai uji lipat gel surimi lele meningkat setelah dicuci 3 kali dan 4 kali yaitu dari 1,8 pada pencucian 1 kali menjadi 3,88 pada pencucian 4 kali.

Nilai uji gigit menunjukkan frekuensi pencucian meningkatkan nilaidari cukup kuat pada pencucian 1 dan 2 kali menjadi kuat pada

Tabel 5 Nilai uji lipat dan uji gigit gel surimi lele dengan frekuensi pencucian berbeda

\begin{tabular}{ccc}
\hline Perlakuan & Uji Lipat & Uji Gigit \\
\hline Pencucian 1 kali & $3,43 \pm 0,90^{\mathrm{ab}}$ & $6,67 \pm 1,06^{\mathrm{a}}$ \\
Pencucian 2 kali & $3,47 \pm 0,63^{\mathrm{b}}$ & $6,90 \pm 0,76^{\mathrm{a}}$ \\
Pencucian 3 kali & $4,23 \pm 0,73^{\mathrm{c}}$ & $7,87 \pm 0,73^{\mathrm{bc}}$ \\
Pencucian 4 kali & $4,67 \pm 0,55^{\mathrm{d}}$ & $8,23 \pm 0,77^{\mathrm{c}}$ \\
\hline
\end{tabular}


pencucian 3 dan 4 kali. Wijayanti et al. (2012) melaporkan bahwa bertambahnya frekuensi pencucian meningkatkan nilai uji gigit dari 5,4 menjadi 6,94 .

\section{KESIMPULAN}

Pencucian 3x menurunkan protein, lemak, dan meningkatkan kadar air, namun tidak berpengaruh terhadap mineral dan asam amino.

\section{Ucapan Terima kasih}

Ucapan terima kasih penulis sampaikan kepada Universitas Diponegori yang mendanai penelitian ini melalui PNBP UNDIP tahun 2013.

\section{DAFTAR PUSTAKA}

Adu DA, Babbitt JK, Crawford DL. 1983. Effect of washing on the nutritional and quality characteristics of dried minced rockfish flesh. Journal of food Science 48:1053-1060.

Amiza MA, Ain KN. 2012. Effect of washing cycle and salt addition on the properties of gel from silver catfish (Pangasius Sp.) surimi. UMT 11th International Annual Symposium on Sustainability Science and Management 09th - 11th July 2012, Terengganu, Malaysia.

[AOAC] Association of Official Analytical Chemist. 2005. Official Methods of Analysis of The Association of Official Analytical Chemist. Arlington, Virginia USA: AOAC Inc.

Asgharzadeh A, Shabanpour B, Aubourg SP, Hosseini H. 2010. Chemical changes in silver carp (Hypophthalmichthys molitrix) minced muscle during frozen storage: effect of a previous washing process. Grasas $Y$ Aceites 61(1):95-101.

Balange AK. 2009. Enhancement of gel strength of surimi using oxidized phenolic compound. [disertasi]. Tambon Ruesamilae, Thailand: Food Science dan Technology Prince of Songkla University.

Balange AK, Benjakul S. 2009. Enhancement of gel strength of bigeye snapper (Priacanthus tayenus) surimi using oxidised phenolic compounds. Food Chemistry 113:61-70.

Berkel BM, Boogaard B, Heijnen C. 2004. Preservation of Fish and Meat. Ed ke3. Wageningen, Netherland: Agromisa Foundation.

Chaijan M, Panpipat W, Benjakul S. 2010. Physicochemical properties and gelforming ability of surimi from three species of mackerel caught in Southern Thailand. Food Chem. 121: 85-92.

Direktorat Jenderal Perikanan Budidaya Kementerian Kelautan dan Perikanan. 2009. Produksi Budidaya tahun 2009. http://www.perikanan-budidaya.kkp.go.i. (25 Februari, 2011)

Hadiwiyoto S. 1993. Dasar-dasar Teknologi Hasil Perikanan. Yogyakarta: Liberty.

Hass M E. 2014. Lysine. http://www.healthy.net/ scr/article (diunduh 21 Februari 2014)

Hoke ME, Jahncke ML, Silva JL, Hearnsberger JO, Chamul RS, Suriyaphan O. 2000. Stability of washed frozen mince from channel catfish frames. Journal of Food Science 65(6): 1083-1086.

Hossain MI, Kamal MM, Shikha FH, Hoque MdS. 2004. Effect of washing dan salt concentration on the gel forming ability of two tropical fish species. International Journal of Agriculture dan Biology 6(5): 762-766.

Karthikeyan M, Dileep AO, Shamasundar BA. 2006. Effect of water washing on the functional and rheological properties of proteins from threadfin bream (Nemipterus japonicus) meat. International Journal of Food Science and Technology 41:1002-1010.

Kim BY, Park JW. 2000. Rheologi and texture properties of surimi gels. Di dalam: Park JW, editor. Surimi dan Surimi Seafood. New York: Marcell Decker Inc. hlm 267-324.

[KKP] Kementerian Kelautan dan Perikanan. 2011a. Data Indikator Kinerja Umum Kelautan dan Perikanan Tahun 2010. Jakarta: Pusat Data Statistika dan Informasi Kementerian Kelautan dan Perikanan.

[KKP] Kementerian Kelautan dan Perikanan. 
2011b. Statistik Kelautan dan Perikanan 2011. Jakarta: Pusat Data Statistika dan Informasi Kementerian Kelautan dan Perikanan.

Lin TM, Park JW. 1997. Effective washing conditions reduce water usage for surimi processing. J. Aquat. Food Prod. Tech. 6(2): 65-79.

Luo X, Yang R, Zhao W, Cheng Z, Jiang X. 2010. Gelling properties of Spanish mackerel (Scomberomorus niphonius) surimi as affected by washing process and high pressure. International Journal of Food Engineering 6(4): Article 3.

Mallick HN. 2007. Review article, understanding safety of glutamate in food and brain. Indian Journal Physiol Pharmacol. 51(3):216-234.

Osibona AO, Kusemiju K, Akande GR. 2009. Fatty acid composition and amino acid profile of two freshwater species, african catfish (Clarias gariepinus) and tilapia (Tilapia zillii.) African Journal of Food, Agriculture, Nutrition and Development 9(1):608-621.

Park JW, Morrissey MT. 2000. Manufacturing of surimi from light muscle fish. Di dalam: Park JW, editor. Surimi dan Surimi Seafood. New York: Marcell Decker Inc. hlm 23-58.

Park JW, Lin TM John. 2005. Manufacturing and evaluation. Di dalam: Park JW, editor. Surimi dan Surimi Seafood. New York: Marcell Decker Inc. hlm 33-98.

Rasekh JG, Waters ME, Sidwell VD. 1980. The Effect of Washing on the Quality Characteristics of Minced Fresh Croaker, 'Micropogon undulatus', Held in Frozen Storage. Marine Fisheries Review. p: 26-30.

Richardson JM. 1999. Comparison of surimi and solubilized surimi for kamaboko production from farm chinock salmon. [tesis]. Vancouver, Canada: Departemen of
Food Science, Faculty of Graduate Studies, British Columbia University.

Shahidi F, Botta JR. 1994. Seafood Chemistry, Processing Technology dan Quality. London: Blackie Academic and Professional, Chapman and Hall.

Steel RGD, Torrie JH. 1993. Prinsip dan Prosedur Statistika. Sumantri B, penerjemah. Jakarta: PT Gramedia Pustaka Utama. Terjemahan dari: Principles and Procedures of Statistics.

Suvanich V, Jahncke ML, Marshall DL. 2000. Changes in selected chemical quality characteristics of channel catfish frame mince during chill and frozen storage. Journal of Food Science 65(1): 24-29.

Suvanich V, Marshall DL. 1998. Influence of storage time and temperature on quality of catfish (Ictalurus punctatus) frames. Journal Aquatic Food Product Technoogy 7:61-76.

Suzuki T. 1981. Fish dan Krill Protein in Processing Technology. London: Applied Science Publishing Ltd.

Synowiecki J, Hall D, Shahidi F. 1992. Effect of washing on the amino acid composition and connective tissue content of seal meat. Journal of Muscle Foods 3(1): 25-31.

[WHO] World Health Organization. 2007. Protein and Amino Acid Requirements in Human Nutrition. Geneva Switzerland: WHO.

Wijayanti I, Santoso J, Jacoeb AM. 2012. Pengaruh frekuensi pencucian terhadap karakteristik gel surimi ikan lele dumbo (Clarias gariepinus). Jurnal Saintek Perikanan 8(1): 31-36.

Zhao D, Li Q, Duan E, Li H, Shen X. 2009. Solubility of 1-lysine hydrochloride in dimethyl sulfoxide, methanol, ethanol, water, and glycol between (283 and 323). Journal of Chemical and Engineering. 54(7):2126-2129. 